\title{
Imaging Analysis of Onodi Cells on Cone-Beam Computed Tomography
}

\author{
Ibrahim K. Ali ${ }^{1}$ Kaustubh Sansare ${ }^{1}$ Freny Karjodkar ${ }^{1} \quad$ Mohd Saalim $^{1}$ \\ ${ }^{1}$ Department of Oral Medicine and Radiology, Nair Hospital Dental
College, Mumbai, India \\ Int Arch Otorhinolaryngol 2020;24(3):e319-e322. \\ Address for correspondence Ibrahim K. Ali, MDS, Department of Oral \\ Medicine and Radiology, Nair Hospital Dental College, Mumbai, \\ 400008, India (e-mail: ibrahimali2589@gmail.com).
}

\begin{abstract}
Keywords

- onodi cell

- optic neuritis

- cone-beam computed tomography

- endonasal transsphenoidal technique

Introduction Onodi cells are the most posterior ethmoid air cells, and extend superolaterally to the sphenoid sinus. The identification of Onodi cells is essential to because they can have some significant anatomic variations and relationships to vital adjacent structures, like the optic canal, the sphenoid sinus, and the internal carotid artery.

Objective The present study aimed to assess the prevalence of Onodi cells and their position with respect to sphenoid sinus. To the authors' best knowledge, this is the first study that uses cone-beam computed tomography ( $C B C T)$ to assess the prevalence and position of Onodi cells.

Methods We collected CBCT scan records from November 1st, 2016, to July 31st, 2017; the patients who fulfilled the eligibility criteria were included in the present study. The CBCT scans were reviewed by two independent observers. The descriptive statistics was performed using the Statistical Package for the Social Sciences (SPSS, SPSS, Inc., Chicago IL, US) software, version 17.0. A cross-tabulation of gender with the presence and position of Onodi cells was evaluated using the Chi-squared $\left(x^{2}\right)$ test. The inter- and intraobserver agreements were evaluated using Kappa ( $\mathrm{k}$ ) statistics.

Results Onodi cells were identified in $86(42.8 \%)$ out of 201 patients. A subgroup analysis revealed that Onodi cells were present in 45 (43.3\%) female and 41 (42.3\%) male patients. The position of the Onodi cells was superior with respect to the sphenoid sinus in $43(50 \%)$ of the patients, superolateral in $36(41.9 \%)$, and lateral to the sphenoid sinus in 7 (8.1\%) of the patients.

Conclusion The present study indicated a high prevalence of Onodi cells, with approximately equal distribution among males and females, and mostly superior in position in relation to the sphenoid sinus.
\end{abstract}

\section{Introduction}

Dr. Adolfo Onodi described Onodi cells as the most posterior ethmoid air cells that extend superolaterally to the sphenoid sinus, and are intimately related to the optic nerve. During sinus surgeries, unrecognized Onodi cells can result in serious damage to the optic nerve. ${ }^{1,2}$ Currently, there has been more concern to define these cells and their variations as

received

April 16, 2018

accepted

September 8, 2019

published online

December 13, 2019 10.1055/s-0039-1698779. ISSN 1809-9777. they pertain to the endoscopic sinus and endonasal sellar surgery. The identification of Onodi cells is essential because they can have some significant anatomic variations and relationships to vital adjacent structures like the optic canal, the sphenoid sinus and the internal carotid artery. The endonasal transsphenoidal technique is the recent preferred approach for the resection of pituitary adenomas. ${ }^{3}$ This
Copyright $\odot 2020$ by Thieme Revinter Publicações Ltda, Rio de Janeiro, Brazil
License terms

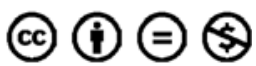


technique is chosen over the transcranial route due to its less invasive nature. As this procedure is gaining increasing popularity, it is imperative to unambiguously identify the surrounding anatomy to ensure a safe and precise dissection. ${ }^{4}$ During surgery, the identification of Onodi cells is crucial to maximize exposure and reduce the risk of injury to the surrounding structures. ${ }^{5}$ The prevalence of Onodi cells varies with different identification methods.

Driben et $\mathrm{al}^{6}$ reported Onodi cell prevalence on cadaveric endoscopic examinations and axial section of computed tomography (CT) examinations that was of $39 \%$ and $7 \%$ respectively. Weinberger et $\mathrm{al}^{7}$ reported $14 \%$ and $8 \%$ of prevalence on cadaveric endoscopic versus coronal CT examinations respectively. Yeoh and $\operatorname{Tan}^{8}$ and Thanaviratananich et $\mathrm{al}^{9}$ reported prevalences of $51 \%$ and $60 \%$ respectively on Asian cadavers by performing endoscopic examinations. These studies reveal that the prevalence by endoscopy is higher than that by radiography.

Arslan et al, ${ }^{10}$ Unal et al, ${ }^{11}$ and Nitinavakarn et al ${ }^{12}$ studied two views (axial and coronal) of CT scans and reported prevalences of $12 \%, 8 \%$ and $25 \%$ respectively. Bansberg et $\mathrm{al}^{13}$ and Batra et $\mathrm{al}^{14}$ reported a greater prevalence of Onodi cells when they examined three views of the CT in contrast with two views of the CT. Chmielik and Chmielik ${ }^{15}$ reported a prevalence of $39.8 \%$ of Onodi cells by examining three CT planes. The aforementioned studies reveal that when the scan data are viewed in all three planes, the radiographic prevalence improves. To overcome this low prevalence, the examination of these cells in different sections is recommended.

Cone-beam computed tomography (CBCT) is a recent imaging modality that enables the visualization of Onodi cells in different planes with various advantages over computed tomography (CT). The literature search did not reveal any study investigating the prevalence of Onodi cells using CBCT. To the authors' best knowledge, the present is the first study that uses CBCT to assess the prevalence and position of Onodi cells with respect to the sphenoid sinus.

\section{Materials and Methods}

The CBCT scan records from March 2015 to February 2016 were retrieved from the digital imaging and communications in medicine archive folder of our institution. These scans had been used earlier in a study involving accessory maxillary ostium and Haller cells. The Z statistic was of 1.96 for the $95 \%$ confidence interval, $7 \%$ minimum allowable risk, power of $80 \%$ and the expected prevalence of 0.39 (39\%) were taken from this previous study. ${ }^{15}$ The minimum sample size calculated was 189; therefore, we decided to include 201 CBCT scans from the archive folder that fulfilled the inclusion criteria.

The CBCT scans were reviewed by two independent observers (radiologists with a minimum of 5 years of experience in interpreting scans). The subjects who had had trauma or had history of surgery in the sinus region, or tumor causing distortion of the anatomy, were excluded from the present study. The CBCT scans were taken using the Kodak CS 9300 3D system (Carestream Health, Inc., Rochester, NY, US) with field of view of $17 \times 13.5 \mathrm{~cm}$, Voxel size of $250 \times 250 \times 250 \mu \mathrm{m}$, $10 \mathrm{~mA}, \mathrm{X}$-ray pulse time of $30 \mathrm{~ms}$, and $70 \mathrm{kVp}$. A training session to precisely identify Onodi cells was planned for the observers before the beginning of the study. The CBCT images were evaluated using a three-dimensional imaging communication software (Carestream Health, Inc., Rochester, NY, US) on a workstation with a 19-inchHP Compaq LE1911 LCD monitor (Hewlett-Packard, Palo Alto, CA, US). The scans were independently analyzed by the two observers, who were allowed to use the contrast and zoom tools. A total of 50 scans were reviewed twice at an interval of 15 days by the same observers to calculate intraobserver agreement using Kappa (к) statistics. The descriptive statistics was performed using the Statistical Package for the Social Sciences (SPSS, SPSS, Inc., Chicago IL, US) software, version 17.0. A cross-tabulation of gender with the presence and position of Onodi cells was evaluated using the Chi-squared $\left(\mathrm{X}^{2}\right)$ test.

\section{Results}

The data of the 201 patients was included according to the eligibility criteria. Of these, 104 patients were female and 97 were male. Onodi cells (-Fig.1) were identified in 86 patients (42.8\%). The age ranged from 16 to 85 years (mean: 37 years). The descriptive analysis revealed that Onodi cells were present in 45 (43.3\%) females and 41 (42.3\%) males. Onodi cells were present superior in position
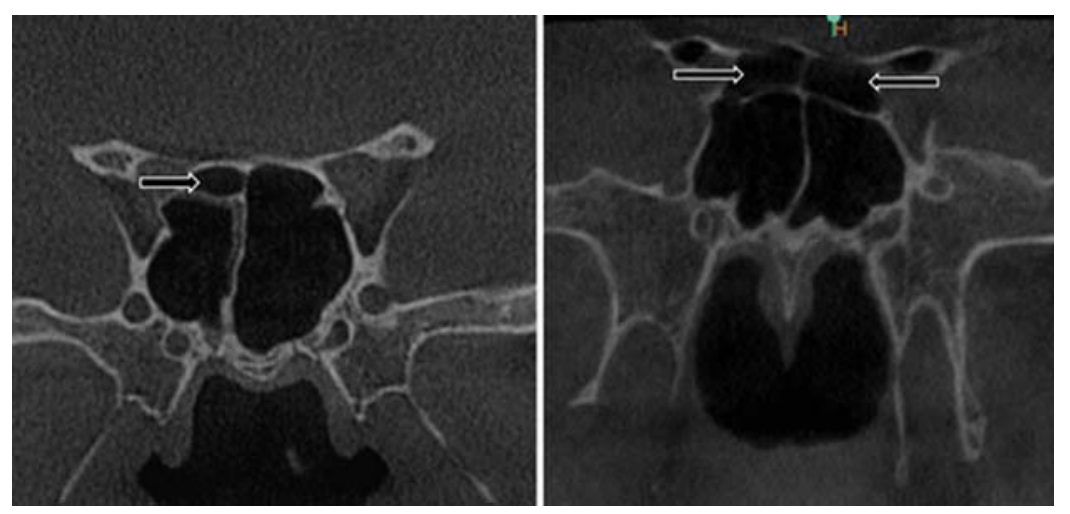

Fig. 1 Cone-beam computed tomography ( $C B C T)$ scan in coronal view showing Onodi cells (black arrows). 
Table 1 Association of gender and the presence of Onodi cells (Chi-squared test)

\begin{tabular}{|l|l|l|l|}
\hline \multirow{2}{*}{ Gender } & \multicolumn{2}{|l|}{ Onodi cells } & \multirow{2}{*}{$\begin{array}{l}\text { Total } \\
\text { n (\%) }\end{array}$} \\
\cline { 2 - 3 } & Present $\mathbf{n}(\%)$ & Absent $\mathbf{n}(\%)$ & \\
\hline Male & $41(42.3)$ & $56(57.7)$ & $97(100)$ \\
\hline Female & $45(43.3)$ & $59(56.7)$ & $104(100)$ \\
\hline Total & $86(42.8)$ & $115(57.2)$ & $201(100)$ \\
\hline
\end{tabular}

Note: $p$-value: 0.886 .

with respect to the sphenoid sinus in $43(50 \%)$ of the patients, superolateral in 36 (41.9\%), and lateral to the sphenoid sinus in $7(8.1 \%)$ of the patients. No significant association was observed on the $X^{2}$ test between gender and presence of Onodi cells ( - Table 1 ), or regarding the position of the Onodi cells with respect to the sphenoid sinus (-Table 2). The $\mathrm{K}$ score indicated almost perfect interobserver (0.854) and intraobserver (0.921) agreements.

\section{Discussion}

As endoscopic skull base and endoscopic transsphenoidal surgeries become common, it is essential to identify the intricate anatomy of the base of the skull. The Onodi cell is the most posterior ethmoid cell that pneumatizes superiorly and laterally to the sphenoid sinus, in close proximity to the optic nerve canal and internal carotid artery. Earlier studies on CT scans reported that the prevalence of Onodi cells ranges from $8 \%$ to $24 \%,{ }^{6,16-19}$ whereas cadaveric studies showed an increased prevalence range of $42 \%$ to $60 \%{ }^{7,9,20,21}$ Shin et a ${ }^{22}$ analyzed 162 preoperative CT scans and intraoperative endoscopic endonasal results and reported an incidence of Onodi cells on the preoperative CT of $32.7 \%$, and of $33.3 \%$ during transsphenoidal surgery, thus demonstrating a good correlation between CT and intraoperative findings. There has been a difference in the prevalence of Onodi cells in cadaveric and radiographic anatomical studies. This dilemma is essential to address, as preoperative planning is key to safe and successful surgical procedures. ${ }^{23}$ The present study found a prevalence of $42.8 \%$ of Onodi cells, which is higher than the prevalence found in a recently reported study. ${ }^{15}$ The high percentage of Onodi cells in the present study may indicate the usefulness of the CBCT scan in the recognition of bony structures, as in paranasal sinus..$^{24,25}$ The present study provides an evidence of the usefulness of the СВCT technique in the detailed imaging of bony structures of the paranasal sinus region at considerably low radiation doses in contrast to the $\mathrm{CT}$. In the present study, we found an almost equal distribution of Onodi cells among male and female patients. This finding was consistent with that of the study by Tomovic et al. ${ }^{23}$ In the current study, the superior position of Onodi cells was more prevalent; however, Chmielik and Chmielik ${ }^{15}$ reported that the superolateral position was more prevalent in their study. Because of the high prevalence of Onodi cells, it is important to find
Table 2 Association of gender and the position of Onodi cells (Chi-squared test)

\begin{tabular}{|l|l|l|l|l|}
\hline \multirow{2}{*}{ Gender } & \multicolumn{2}{|l|}{ Onodi cells } & \multirow{2}{*}{$\begin{array}{l}\text { Total } \\
\text { n (\%) }\end{array}$} \\
\cline { 2 - 4 } & $\begin{array}{l}\text { Superolateral } \\
\mathbf{n}(\%)\end{array}$ & $\begin{array}{l}\text { Superior } \\
\mathbf{n}(\%)\end{array}$ & $\begin{array}{l}\text { Lateral } \\
\mathbf{n}(\%)\end{array}$ & \\
\hline Male & $17(41.5)$ & $20(48.8)$ & $4(9.8)$ & $41(100)$ \\
\hline Female & $19(42.2)$ & $23(51.1)$ & $3(6.7)$ & $45(100)$ \\
\hline Total & $36(41.9)$ & $43(50)$ & $7(8.1)$ & $86(100)$ \\
\hline
\end{tabular}

Note: $p$-value: 0.870 .

out their exact position and their relationship to the optic nerve, the internal carotid artery and the pituitary gland, because the optic nerve often presents with an Onodi cell. When there are large Onodi cells present, this may lead the surgeon to mistake it for the sphenoidal sinus, and this may result in the surgical excavation of the sinus, which may lead to life-threatening complications. The limitations of this observation are the lack of endoscopic examinations of the patients to confirm the presence and position of the Onodi cells. We advise the performance of a study on the prevalence of Onodi cells on CBCT and CT examinations with endoscopic examinations to compare the results of the two modalities in relation to the gold standard that is the endoscopic finding.

\section{Conclusion}

The present study suggested a high prevalence of Onodi cells, and the superior position was the most common followed by the superolateral position, with approximately equal prevalence among males and females. It is important to obtain CBCT images and review them in different planes before sinus surgeries to know the exact relation of the Onodi cells with important anatomic structures in order to prevent postoperative surgical complications.

Conflict of Interest

The authors have none to disclose.

\section{References}

1 Ónodi A. The Optic Nerve and the Accessory Sinuses of the Nose. William Wood; 1910

2 Stammberger HR, Kennedy DW Anatomic Terminology Group. Paranasal sinuses:anatomic terminology and nomenclature. Ann Otol Rhinol Laryngol Suppl 1995;167:7-16

3 Schwartz T, Anand V. Endoscopic Pituitary Surgery: Endocrine, Neuro-Ophthalmologic and Surgical Management. Thieme; 2011

$4 \mathrm{Kim}$ DH, Hong YK, Jeun SS, et al. How to Expose the Entire Sella Floor With Minimal Manipulation During an Endoscopic Endonasal Transsphenoidal Approach. J Craniofac Surg 2017;28(04): 1005-1006

5 Liu JK, Christiano LD, Patel SK, Tubbs RS, Eloy JA. Surgical nuances for removal of tuberculum sellae meningiomas with optic canal involvement using the endoscopic endonasal extended transsphenoidal transplanum transtuberculum approach. Neurosurg Focus 2011;30(05):E2 
6 Driben JS, Bolger WE, Robles HA, Cable B, Zinreich SJ. The reliability of computerized tomographic detection of the Onodi (Sphenoethmoid) cell. Am J Rhinol 1998;12(02): 105-111

7 Weinberger DG, Anand VK, Al-Rawi M, Cheng HI, Messina AV. Surgical anatomy and variations of the Onodi cell. Am J Rhinol 1996;10:365-370

8 Yeoh KH, Tan KK. The optic nerve in the posterior ethmoid in Asians. Acta Otolaryngol 1994;114(03):329-336

9 Thanaviratananich S, Chaisiwamongkol K, Kraitrakul S, Tangsawad W. The prevalence of an Onodi cell in adult Thai cadavers. Ear Nose Throat J 2003;82(03):200-204

10 Arslan H, Aydinlioğlu A, Bozkurt M, Egeli E. Anatomic variations of the paranasal sinuses: CT examination for endoscopic sinus surgery. Auris Nasus Larynx 1999;26(01):39-48

11 Unal B, Bademci G, Bilgili YK, Batay F, Avci E. Risky anatomic variations of sphenoid sinus for surgery. Surg Radiol Anat 2006;28 (02):195-201

12 Nitinavakarn B, Thanaviratananich S, Sangsilp N. Anatomical variations of the lateral nasal wall and paranasal sinuses: A CT study for endoscopic sinus surgery (ESS) in Thai patients. J Med Assoc Thai 2005;88(06):763-768

13 Bansberg SF, Harner SG, Forbes G. Relationship of the optic nerve to the paranasal sinuses as shown by computed tomography. Otolaryngol Head Neck Surg 1987;96(04):331-335

14 Batra PS, Citardi MJ, Gallivan RP, Roh HJ, Lanza DC. Softwareenabled CT analysis of optic nerve position and paranasal sinus pneumatization patterns. Otolaryngol Head Neck Surg 2004;131 (06):940-945

15 Chmielik LP, Chmielik A. The prevalence of the Onodi cell - Most suitable method of CT evaluation in its detection. Int J Pediatr Otorhinolaryngol 2017;97:202-205
16 Jones NS, Strobl A, Holland I. A study of the CT findings in 100 patients with rhinosinusitis and 100 controls. Clin Otolaryngol Allied Sci 1997;22(01):47-51

17 Keast A, Yelavich S, Dawes P, Lyons B. Anatomical variations of the paranasal sinuses in Polynesian and New Zealand European computerized tomography scans. Otolaryngol Head Neck Surg 2008;139(02):216-221

18 Tan KL, Harvinder S KL T. Prevalence of onodi cells in hospital raja permaisuri bainun, ipoh, malaysia. Med J Malaysia 2010;65(02): 101-102

19 Perez P, Sabate J, Carmona A, Catalina-Herrera CJ. Jimenez-Castellanos J. Anatomical variations in the human paranasal sinus region studied by CT. J Anat 2000;197(pt 2):221-227

20 Kantarci M, Karasen RM, Alper F, Onbas O, Okur A, Karaman A. Remarkable anatomic variations in paranasal sinus region and their clinical importance. Eur J Radiol 2004;50(03):296-302

21 Yanagisawa E, Weaver EM, Ashikawa R. The Onodi (sphenoethmoid) cell. Ear Nose Throat J 1998;77(08):578-580

22 Shin JH, Kim SW, Hong YK, et al. The Onodi cell: an obstacle to sellar lesions with a transsphenoidal approach. Otolaryngol Head Neck Surg 2011;145(06):1040-1042

23 Tomovic S, Esmaeili A, Chan NJ, et al. High-resolution computed tomography analysis of the prevalence of Onodi cells. Laryngoscope 2012;122(07):1470-1473. DOI: 10.1002/lary.23346

24 Ali IK, Sansare K, Karjodkar FR, Vanga K, Salve P, Pawar AM. Conebeam computed tomography analysis of accessory maxillary ostium and Haller cells: Prevalence and clinical significance. Imaging Sci Dent 2017;47(01):33-37. DOI: 10.5624/isd.2017.47.1.33

25 Ali IK, Sansare K, Karjodkar FR, Salve P. Cone Beam Computed Tomography Assessment of Accessory Infraorbital Foramen and Determination of Infraorbital Foramen Position. J Craniofac Surg 2018;29(02):e124-e126. DOI: 10.1097/SCS.0000000000004120 